\title{
Heat Integration of a Boiler and Its Corresponding Environmental Study in an Oleochemical Production Plant: An Industry Case Study in Malaysia
}

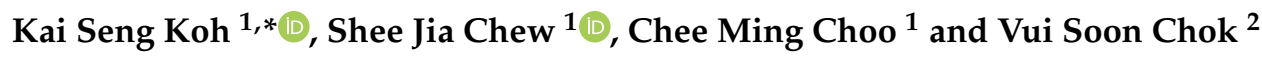 \\ 1 School of Engineering and Physical Science, Heriot-Watt University Malaysia, Putrajaya 62200, Malaysia; \\ leanne_chew@hotmail.com (S.J.C.); c.choo@hw.ac.uk (C.M.C.) \\ 2 KL-Kepong Oleomas Sdn. Bhd, Pulau Indah 42920, Malaysia; vs.chok@klkoleo.com \\ * Correspondence: k.koh@hw.ac.uk; Tel.: +60-8894-3786
}

Received: 11 July 2019; Accepted: 19 September 2019; Published: 4 October 2019

check for updates

\begin{abstract}
The growing demands for oleochemical products are expected to reach approximately RM 157.59 billion by 2026 due to an increased drive from the food and beverages, chemicals, and pharmaceutical industries. However, this will lead to an increase in energy consumption and subsequent flue gas emission. Proper utilization of waste gas recovery systems is thus a major research area, focusing on reducing fuel consumption and emissions of greenhouse gases without affecting process performance. In this paper, a palm oil-based oleochemical plant is studied. The fuel consumption and emission of flue gas from a thermal oil boiler were measured and the feasibility of implementation of a waste heat recovery system and its environmental impact study. The results show that the implementation of such a system can reduce natural fuel gas consumption by $17.29 \%$ and approximately $149.29 \mathrm{t}$ per annum of carbon dioxide gas $\left(\mathrm{CO}_{2}\right)$. Moreover, the concentration of $\mathrm{CO}_{2}$ released into highly-populated communities is estimated through a Gaussian Plume Model at different wind speed conditions. The preliminary results show that the $\mathrm{CO}_{2}$ concentration at two locations - an apartment and a local school located within $1.5 \mathrm{~km}$ of the plant-is well below the concentration limit of $1.938 \mathrm{~g} / \mathrm{m}^{3}$ recommended by the Wisconsin Department of Health and Services.
\end{abstract}

Keywords: waste heat recovery system; Gaussian Plume model; environmental impact; carbon footprint

\section{Introduction}

Oleochemical products can be derived from animal fats or vegetable oils. Since vegetable oils account for nearly $80 \%$ of the total fat and oil production, it is also the main source for oleochemical production, especially from palm, coconut, soybean, and sunflower [1,2]. The oil extracted from the flesh of the oil palm fruit (species Elaeis Guineensis Jacq.), in its native setting, is generally a vibrant orange colour. Originating in South Africa, this fine vegetation was introduced to Malaysia in the early 1870s by the British and was planted commercially in 1917 [3]. Being the world's second-largest palm oil exporter (after its neighbouring country, Indonesia), Malaysia accounts for $39 \%$ and $44 \%$ of the global production and exportation, respectively. Most of the oleochemical products in Malaysia are largely derived from palm oil $[4,5]$. With the global oleochemical market showed increase in demand since 2014 owing to increasing petrochemical prices and rising environmental concerns [6], the energy demand for the production process in Malaysia is expected to follow suit [7,8]—chemical manufacturing accounted for $12 \%$ of the country's total energy consumption in 2016. Malaysia is, therefore, expected to experience an increasing demand for energy consumption and a subsequent rise in carbon dioxide gas emission [9]. Faced with global warming and increasing fuel prices, manufacturing industries 
are constantly looking for ways to reduce greenhouse gases and fuel consumption caused by their processes. Proper utilization of waste gas recovery systems has, therefore, become a major research area for this industry, focusing on reducing environmental impacts without affecting process performance.

Heat integration (HI) is an industrial technique used to minimize energy consumption and maximize thermal energy recovery. Albeit the technique was first introduced by Linnhoff and Flower to maximize utility cost-saving through waste heat recovery in the 1970s, systematic methods to optimize heat recovery, cost-saving and greenhouse gas emissions are still studied today $[10,11]$. The development of the $\mathrm{HI}$ technique over the past 40 years through pinch analysis and mathematical programming was reviewed by Klemeš et al. in 2012 [12]. They concluded that recent overviews of $\mathrm{HI}$ focus on the sustainability of the technique in current operating processes [12]. HI is currently streamlined into two approaches: HI within individual process (waste heat recovery system), also referred to as intra-plant HI; and total site HI system, which is also known as inter-plant HI.

Largely practiced at plants, total site heat integration (TSHI) incorporates a multitude of processes that are linked to a central utility system, tying together services and production deliverables [13]. Amir H. Tarighaleslami et. al. studied different approaches to TSHI and compared two methods-conventional total site targeting (CTST) and unified total site targeting (UTST). The latter utilizes total process-level utility targets as the basis for total site utility targets, whereas CTST is similar to pinch analysis, where excess heat is produced (surplus) or absorbed (deficit) by the process. Table 1 shows a comparison of both techniques: It was found that the recovery targets in the UTST method are slightly lower compared to CTST; however, they have more realistic expectations [14]. Although TSHI reduces energy consumption and resolves waste heat-caused conflicts, the operability of such a system should be further discussed, as the costs and energy produced are highly dependent on retrofitting functions (operability and implementation of a heat exchanger network). Sofie Marton et. al. dissected the operability of heat integration into four subsequent categories: flexibility, controllability, start-up and shutdown procedures, and reliability of the system. Such implementations have required certain changes in operations, resulting in additional constraints in system design [15]. Therefore, such systems require decisive planning and careful consideration upon implementation. Peng et. al. have extensively studied comprehensive planning and framework design for TSHI. Owing to their efforts, the factors that have a direct impact on the feasibility of integrating industrial clusters with renewable energy have been identified and discussed; they include economic feasibility and system reliability. The economy is a major defining factor for project feasibility; heavily influenced by the price of fossil fuel, it has a direct impact on payback time in investments. The advancement of new technology is expected to reduce the cost of implementation of this current broadly-accepted technology. Subsequently, the period of implementation is of paramount importance in defining the feasibility of a project from an economic perspective. In addition, the life cycle of key operating units such as boilers and heat exchangers should be further studied to minimise the impacts of equipment breakdown on production, simultaneously maximising the reliability of the TSHI system [16].

Table 1. Comparison between UTST and CTST methods [14].

\begin{tabular}{ccc}
\hline TSHI APPROACHES & UTST & CTST \\
\hline $\begin{array}{c}\text { Matching of Utility Heat } \\
\text { Exchanger }\end{array}$ & Series & Series and Parallel \\
Drawback of System & $\begin{array}{c}\text { Slightly lower heat recovery } \\
\text { targets }\end{array}$ & $\begin{array}{c}\text { Dependency on separate processes, resulting in } \\
\text { complications with regards to operation and control. }\end{array}$ \\
\hline
\end{tabular}

Meanwhile, with the rapid growth of industrial development, it is essential to keep air quality in check to avoid adverse impacts on human health and biodiversity. Therefore, the Department of Environment (DOE) Malaysia has been entrusted with the task of monitoring air quality nationwide and controlling new industry development projects through the Environmental Impact Assessment Order (1987). Under this order, DOE requires the Environmental Impact Assessment (EIA) reports of prescribed industrial activities to be submitted for approval before a project is implemented. The 
reports will be assessed based on the Environmental Quality (Clean Air) Regulation 1978 enforced by DOE in limiting and controlling the air pollutant emissions. The regulation lists factors of air pollution including the location of industrial facilities adjacent to residential areas, waste burning, and emission of dark smoke and air pollutants, which serve as a guideline for DOE and industries in order to protect air quality and reduce air pollution.

Currently, most oleochemical plants in Malaysia use boilers as a heat source. The technical standards for boilers used in heat and power generation as set by the Federal Government Gazette Malaysia are shown in Table A1, whereas the standards set for stack gas emissions under the Environmental Quality (Clean Air) Regulation 1978 are as listed in Table A2. One disadvantage of boiler use is continuous emission of flue gas during the combustion process. Hence, it is important to conduct an air quality assessment to minimise its impact on the environment. A few steps are required in an air quality assessment. Firstly, a site survey is conducted to assess the impact of nearby existing industrial activities on air quality. Therefore, a careful layout of monitoring points is required to effectively assess existing air pollution sources near the proposed development. The data required to evaluate the cumulative impact of air pollutant emissions such as air pollutant source inventory, stack emission data and ambient air quality can be obtained directly from the surrounding industrial concerns or through DOE. After the collection of data, modelling of air quality is carried out to assess the air pollutant concentration emitted during the industrial activity. There are several factors to be considered, such as stack height and emission rate, meteorological conditions, topographic consideration and population consideration. Based on the results, an impact assessment is conducted and mitigating measures are recommended to reduce the environmental impacts below a level of significance [17].

As shown in Figure 1, there are three air quality models: deterministic models, statistical models, and physical models. Deterministic models deal with different types of numerical approximations in the solution, representing relevant atmospheric dispersion physical processes and are highly favourable for long-term plans. On the other hand, statistical models utilise an established statistical relationship between meteorological and other limitations to calculate the ambient air concentration, and these are most favourable for the short-term forecast of concentrations. In physical models, a physical experiment is carried out on a smaller scale to mimic the important features of the original process. Although the variables are easily controlled, physical models tend to incur higher costs compared to the other two models [18]. This paper focuses on deterministic models. There are two types of deterministic models: steady state and time dependent. Unlike time-dependent models, steady state models are independent of time variables. Research performed by Lutman ER et. al. compared the prediction of particle dispersion between the Gaussian plume model and the Lagrangian particle dispersion model. Studies have shown that the differences in modelling results between these two models are insignificant. While the Lagrangian model yields more realistic results, the Gaussian model appears to be a more appropriate tool for environmental assessment as it is more user friendly, though the results tend to be marginally over-estimated [19].

Gaussian plume model is one of the most popular air pollution dispersion models and it is the basis for most of the air pollution modelling software distributed by the EPA [20]. Many researchers have developed advanced Gaussian plume models such as AERMOD, CTDM or ADMS to provide more accurate air quality forecasts [21-25]. Researchers in the University of Messina and University of Catania, Italy carried out a study on the implementation of theoretical Gaussian plume model on a small scale. The results reveal that the error of the Gaussian plume model is consistently below $7 \%$ in all configurations, showing a positive compliance amongst the measured and modelled data. Therefore, it can be concluded that the near real-time nature of the Gaussian plume model makes it a powerful tool to analyse and predict the dispersion of pollutants for regulatory purposes [26,27].

This study presents an innovative heat integration approach to a boiler in an oleochemical production plant, as shown in Figure $2 b$. To harvest waste heat released from the boiler exhaust, an air preheater is proposed to be installed on the thermal oil boiler to allow heat transfer between hot flue gas and fresh air. The main objective of the study is to perform a numerical study on the economic and 
environmental benefits of implementing waste heat recovery around a thermal oil boiler. The dew point of flue gas is also determined to prevent gas species condensation as it can result in stack wall corrosion [28]. Another desired outcome of this approach is a lower level of carbon dioxide emission to the surrounding neighbourhood.

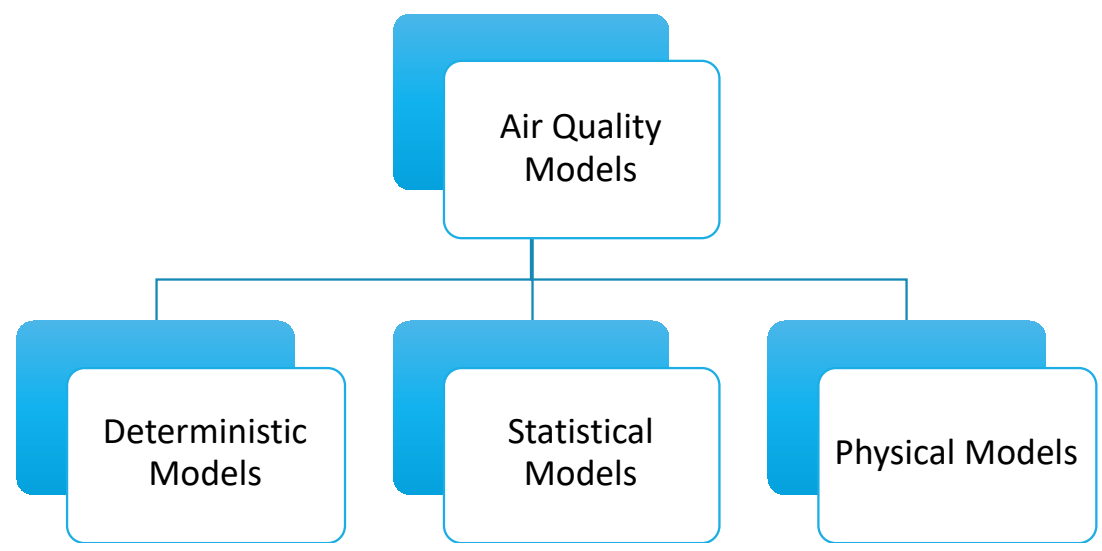

Figure 1. Classification of Air Quality Models [18].

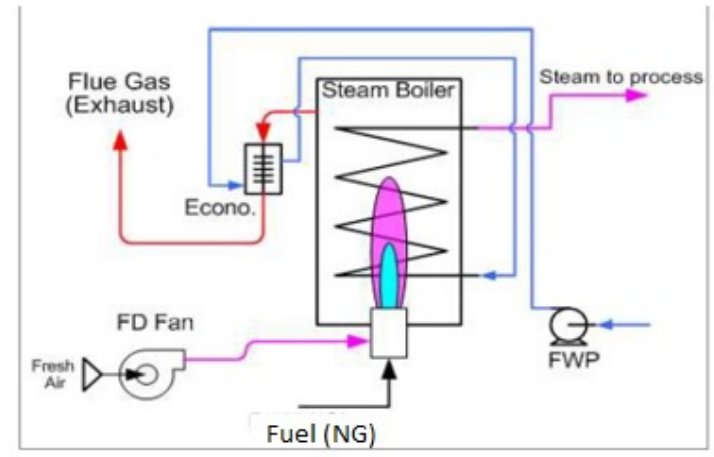

(a)

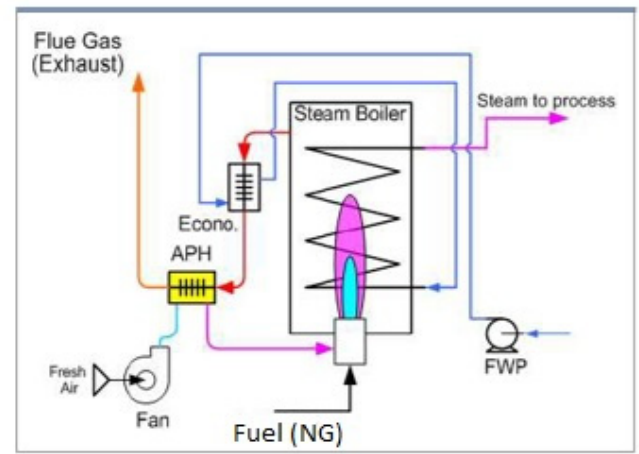

(b)

Figure 2. Heat integration approach to the production plant boiler system. (a). The common setup of a boiler system for a palm oil processing plant; (b) proposed addition of an air preheater (APH) for heat exchange between hot flue gas and fresh air.

\section{Materials and Methods}

The information used in this research is provided by the industry partner or obtained from HYSYS software, AspenTech Locations, Bedford, MA, USA. As this is a collaboration work with an industry partner, Microsoft Excel is used as the calculation tool.

\subsection{Boiler System Heat Integration}

Figure 3 shows the workflow diagram of the boiler system heat integration process, which begins with an input of the boiler data provided by the industry partner: mass flowrate, pressure $(\mathrm{P})$, temperature $(\mathrm{T})$, and the composition of air and natural gas fuel (NG). After inserting the given information and the preferred conditions for the flue gas outlet stream into an Excel spreadsheet, the premix temperature $\left(\mathrm{T}_{\text {premix }}\right)$ and the pressure of both air and NG is determined using enthalpy balance between the two feed streams. The flue gas temperature obtained from the operating data of the industry is then compared to the dew point (DP) of flue gas calculated using the auto goal-seek function in Visual Basic code as shown in Figure A1. As shown in Figure A2, a warning sign will pop out when the temperature of flue gas exceeds the theoretical DP of the flue gas. It is important 
to ensure that the flue gas temperature is well above the theoretical DP to prevent the formation of corrosion in the boiler stack as a result of flue gas condensation.

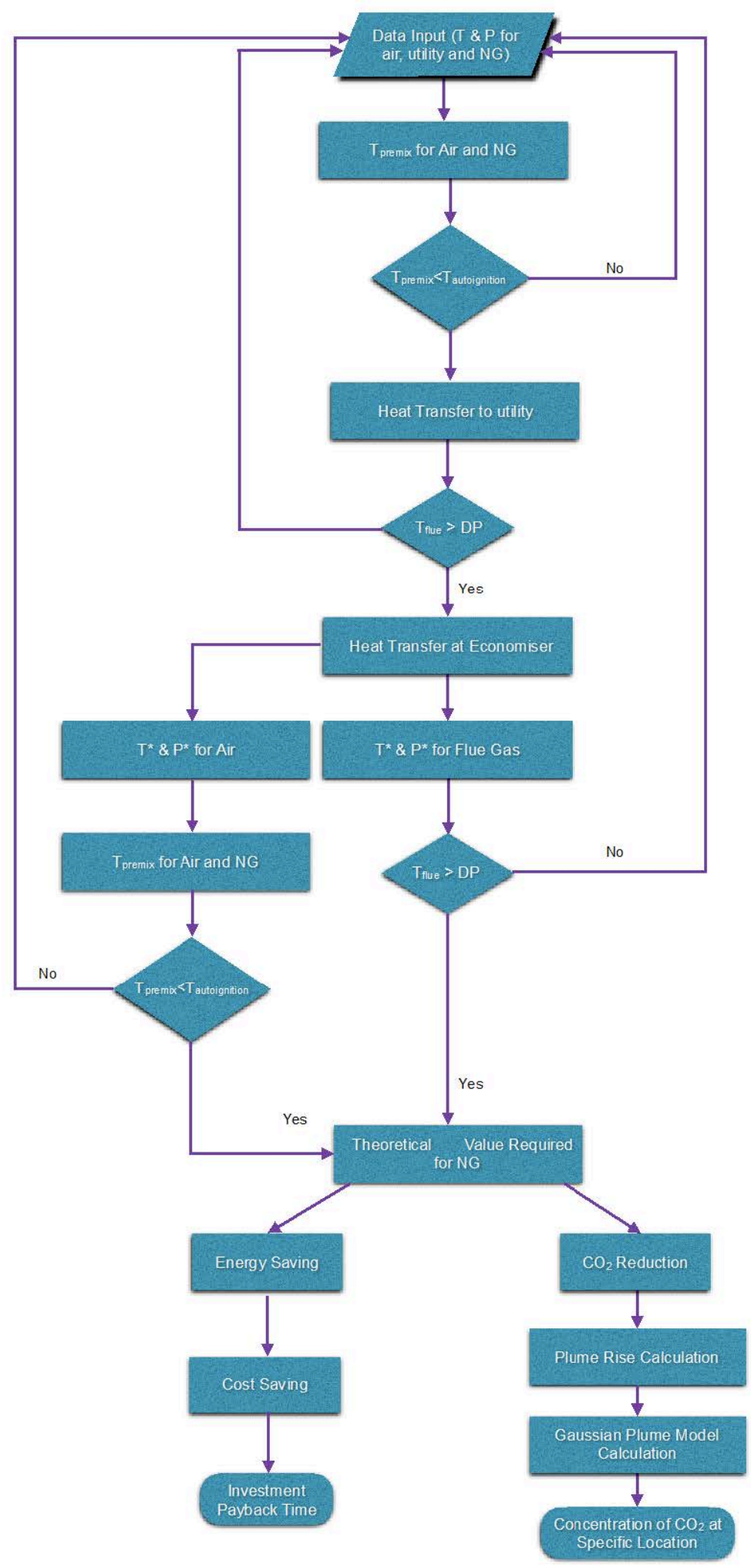

Figure 3. Methodology overview. The heat integration calculation will be obtained prior to carbon dioxide calculation. The flue gas temperature has to be above the dew point before it is used as an input in Gaussian plume model calculation. 
After heat has been exchanged at the economizer (Figure $2 b$ ), the revised temperature and pressure of air and flue gas $\left(\mathrm{T}^{*}\right.$ and $\mathrm{P}^{*}$ ) are determined. The energy and cost savings resulting from the newly conditioned flue gas are calculated through a comparison with the amount of natural gas fuel used before the system is implemented. After obtaining the data for cost saving, the payback time for the investment made in implementing the waste heat recovery system can also be calculated using Equations (1) and (2):

$$
R O R=\frac{\text { Cost saving per year }}{\text { Original investment }} \times 100 \%
$$

$R O R=$ Rate of return

$$
P B T=\frac{100 \%}{R O R}
$$

$P B T=$ Payback period

\subsection{Gausian Plume Model}

Gaussian plume model can be generated by inputting the data provided by the industry source, including the estimated flow rate of carbon dioxide gas released during the heat integration calculation, diameter of the flare stack, gas emission temperature, referential temperature, wind speed, distance between the specific location and the flare stack, and elevation temperature. Then, plume rise calculation under different scenarios, as shown in Figure A3, is carried out. After plume rise and effective stack height are determined, the concentration of carbon dioxide gas released is calculated using Equation (3).

Gaussian Dispersion Equation

$$
C(x, y, z)=\frac{Q}{2 \pi u \sigma_{y} \sigma_{z}}\left[e^{\left(\frac{-(z-h)^{2}}{2 \sigma_{z}^{2}}\right)}+e^{\left(\frac{-(z+h)^{2}}{2 \sigma_{z}^{2}}\right)}\right]\left[e^{\left(\frac{-(y)^{2}}{2 \sigma_{y}^{2}}\right)}\right]
$$

where:

$Q=$ emission rate of carbon dioxide gas from boiler

$u=$ the direction $\mathrm{x}$, defined by the wind speed

$y=$ the direction of the wind of which is perpendicular to horizontal distance

$z=$ vertical direction

$h=$ effective height of plume

$\sigma_{y}$ and $\sigma_{z}=$ dispersion coefficients with respect to the directions in $y$ and $z$

\section{Results and Discussion}

\subsection{A Case Study on Thermal Oil Boiler (B01)}

B01 is a thermal oil boiler with a thermal capacity of $2.5 \mathrm{MW}$ that operates with a load percentage of $80 \%$, and the excess air percentages are set at $8 \%$ to ensure complete combustion of fuel. Using the HYSYS simulation result, the boiler has an efficiency of $\approx 81 \%$ and the air preheater used in waste heat recovery has an efficiency of $\approx 76 \%$ based on the information given by the industry partner. Moreover, B01 is targeted to supply enough thermal energy to increase the temperature of thermal oil fluid by $15^{\circ} \mathrm{C}$, which is the set condition of the production plant. The composition of natural gas fuel (NG) fed into the boiler and the flue gas released upon the combustion of fuel were obtained through data provided by the industry partner and from literature reviews. The dew point of flue gas with such a composition was found to be $52.46^{\circ} \mathrm{C}$ using the Excel spreadsheet mentioned in Section 2.1 while the autoignition temperature of NG was found to be $537^{\circ} \mathrm{C}$. Autoignition temperature was obtained for boiler system safety precaution. All the information of thermal oil boiler B01 as aforementioned are listed in Table 2. The table also shows the fuel consumption and the flue gas emission temperature of $\mathrm{B} 01$ before the implementation of the waste heat recovery system to be approximately $326 \mathrm{t}$ per annum 
and $300{ }^{\circ} \mathrm{C}$ respectively. Due to the high consumption of fuel and flue gas emission temperature, a feasibility study on the implementation of waste heat recovery system on B01 was carried out and the results are shown in the following section.

Table 2. Summary of B01 working conditions.

\begin{tabular}{cc}
\hline \multicolumn{2}{c}{ B01 Working Conditions } \\
\hline Thermal Capacity & $2.5 \mathrm{MW}$ \\
Load Percentage & $80 \%$ \\
Air Excess Percentage & $8 \%$ \\
Utility Temperature Difference & $15^{\circ} \mathrm{C}$ \\
Flue Gas Dew Point & $52.46^{\circ} \mathrm{C}$ \\
Autoignition Temperature & $537^{\circ} \mathrm{C}$ \\
Fuel Consumption & $326.26 \mathrm{~T} /$ Year \\
Flue Gas Emission Temperature & $300^{\circ} \mathrm{C}$ \\
\hline
\end{tabular}

\subsubsection{Waste Heat Recovery}

With the implementation of waste heat recovery as shown in Figure 4, a total of $17.29 \%$ fuel saving was achieved with the outlet flue gas temperature set at $90^{\circ} \mathrm{C}$. It was estimated to yield a saving of around RM 85,000 per annum with fuel price at RM 1.18 per cubic metre. Besides that, with an investment cost between RM 300,000 to RM 600,000 that includes capital cost, installation fee, and commissioning cost, the breakeven point can be achieved within approximately 43 to 85 months from the time the investment is made. In terms of environmental benefits, carbon dioxide gas emission is expected to be reduced by $149.29 \mathrm{t}$ per annum due to the reduction in natural gas fuel consumption. According to a global greenhouse gases monitoring division in United States, the concentration of $\mathrm{CO}_{2}$ in the air has increased around $4 \mathrm{ppm}$ and global temperature has increased by $0.8^{\circ} \mathrm{C}$ from 2018 to 2019 [29,30]. To deal with this problem, in 2017, Malaysia has signed the Paris Agreement, a Multilateral Environmental Agreement aiming to strengthen global response to climate change threats. The energy efficiency action plan aims to reduce 13.113 million $\mathrm{t}$ of $\mathrm{CO}_{2}$ emission by 2030 [31]. If the waste heat recovery system is implemented in thermal oil boiler B01 by 2019, the cumulative reduction of $\mathrm{CO}_{2}$ emissions is expected to be $1642.19 \mathrm{t}$, contributing to $0.01 \%$ of the targeted reduction in $\mathrm{CO}_{2}$ emissions. It should be noted that this contribution is merely from 1 of 13 boilers in the oleochemical complex. If the same technique is applied to all boilers in the complex, the cumulative reduction of $\mathrm{CO}_{2}$ emissions will be significant. The impact of waste heat recovery on B01 is summarized in Table 3 .

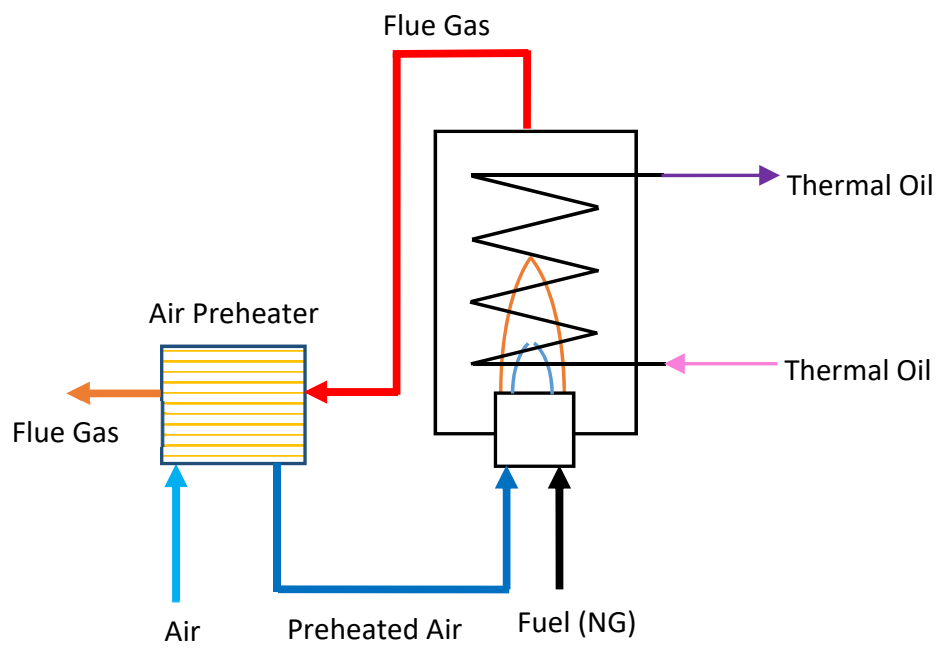

Figure 4. Thermal oil boiler with waste heat recovery system. 
Table 3. Impacts of Implementation of Waste Heat Recovery on B01.

\begin{tabular}{cc}
\hline \multicolumn{2}{c}{ RESULTS } \\
\hline Fuel Saving & $17.29 \%$ \\
Cost Saving & $56.41 \mathrm{~T} /$ Year \\
Payback Time & RM 85k/Year \\
$\mathrm{CO}_{2}$ Reduction & $149.29 \mathrm{M} /$ Year \\
\hline
\end{tabular}

\subsubsection{Gaussian Plume Model}

Flue gas emission is always problematic as a high concentration of flue gas will not only cause an environmental impact but also health issues to the residents living around the industrial area. As shown in Figure 5, the oleochemical plant studied is located approximately $1 \mathrm{~km}$ away from a residential apartment and $1.23 \mathrm{~km}$ away from a public school. Therefore, a Gaussian plume model is used as a reference to study the concentration of carbon dioxide $\left(\mathrm{CO}_{2}\right)$ released at these two locations before and after the heat integration (waste heat recovery) was carried out.

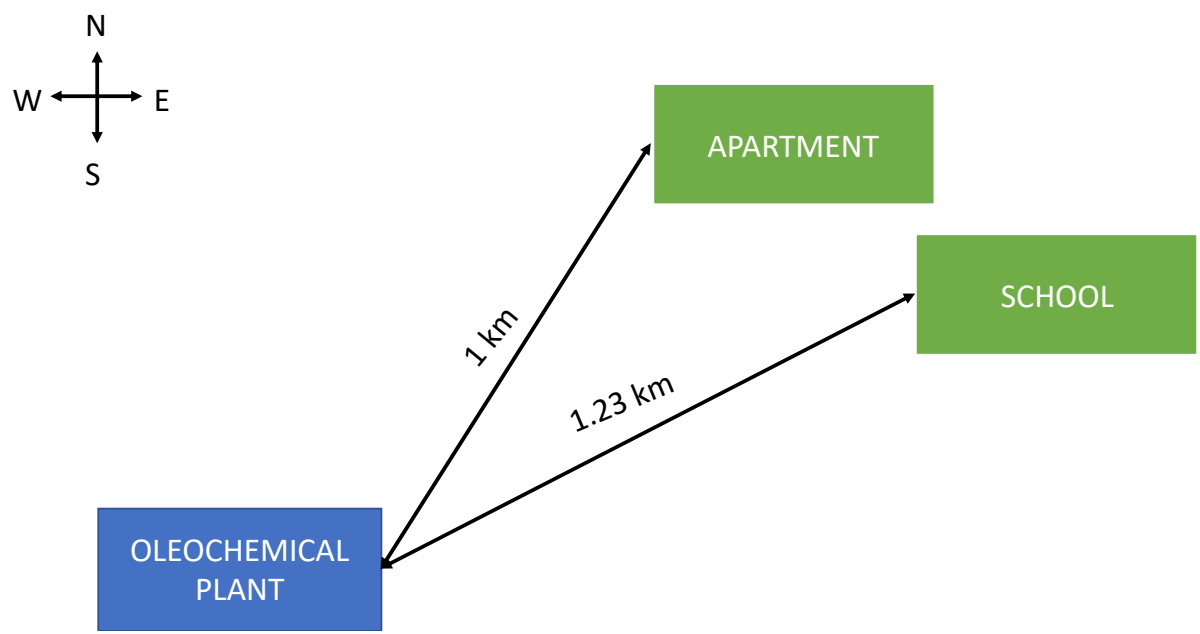

Figure 5. Schematic drawing of location studied.

The study includes three scenarios of different wind speed: minimum wind speed of $3 \mathrm{~km} / \mathrm{h}$, average wind speed of $7.6 \mathrm{~km} / \mathrm{h}$, and maximum wind speed of $14.8 \mathrm{~km} / \mathrm{h}$. The data on wind speed is obtained from the local meteorological department. $\mathrm{CO}_{2}$ concentration is found to be highest under calm conditions, where the wind speed is less than $1 \mathrm{~m} / \mathrm{s}$. On the other hand, under crosswind conditions, where the wind is blown perpendicularly to the direction of particle travel, $\mathrm{CO}_{2}$ concentration is found to be lowest in all three scenarios due to a high dispersion and dilution rate. This paper focuses solely on case studies under calm conditions with minimum wind speed as shown in Figure 6 because these cases yield the most significant environmental impact on the neighbourhood. With the implementation of waste heat recovery between flue gas and inlet air, $\mathrm{CO}_{2}$ concentration at the residential apartment is reduced from $87.77 \mathrm{mg} / \mathrm{m}^{3}$ to $62.80 \mathrm{mg} / \mathrm{m}^{3}$ under calm conditions at minimum wind speed [32]. Meanwhile, the $\mathrm{CO}_{2}$ concentration generated at the public school is much lower than the concentration at the residential area. This is expected as the school is located at a greater distance from the oleochemical plant compared to the distance between the residential apartment and the plant. As presented, the $\mathrm{CO}_{2}$ concentration at the school is reduced from $31.51 \mathrm{mg} / \mathrm{m}^{3}$ to $23.32 \mathrm{mg} / \mathrm{m}^{3}$ after the application of waste heat recovery. Taking into account the $785 \mathrm{mg} / \mathrm{m}^{3}$ of $\mathrm{CO}_{2}$ concentration already in the air, it was found that the $\mathrm{CO}_{2}$ emissions at both the residential and school areas are $847.8 \mathrm{mg} / \mathrm{m}^{3}$ and $808.32 \mathrm{mg} / \mathrm{m}^{3}$ respectively. These concentrations are much lower than the concentration limit of $1938 \mathrm{mg} / \mathrm{m}^{3}$ set by the Wisconsin Department of Health and Services, which is classified as poor air quality where complaints of drowsiness are received [33]. 


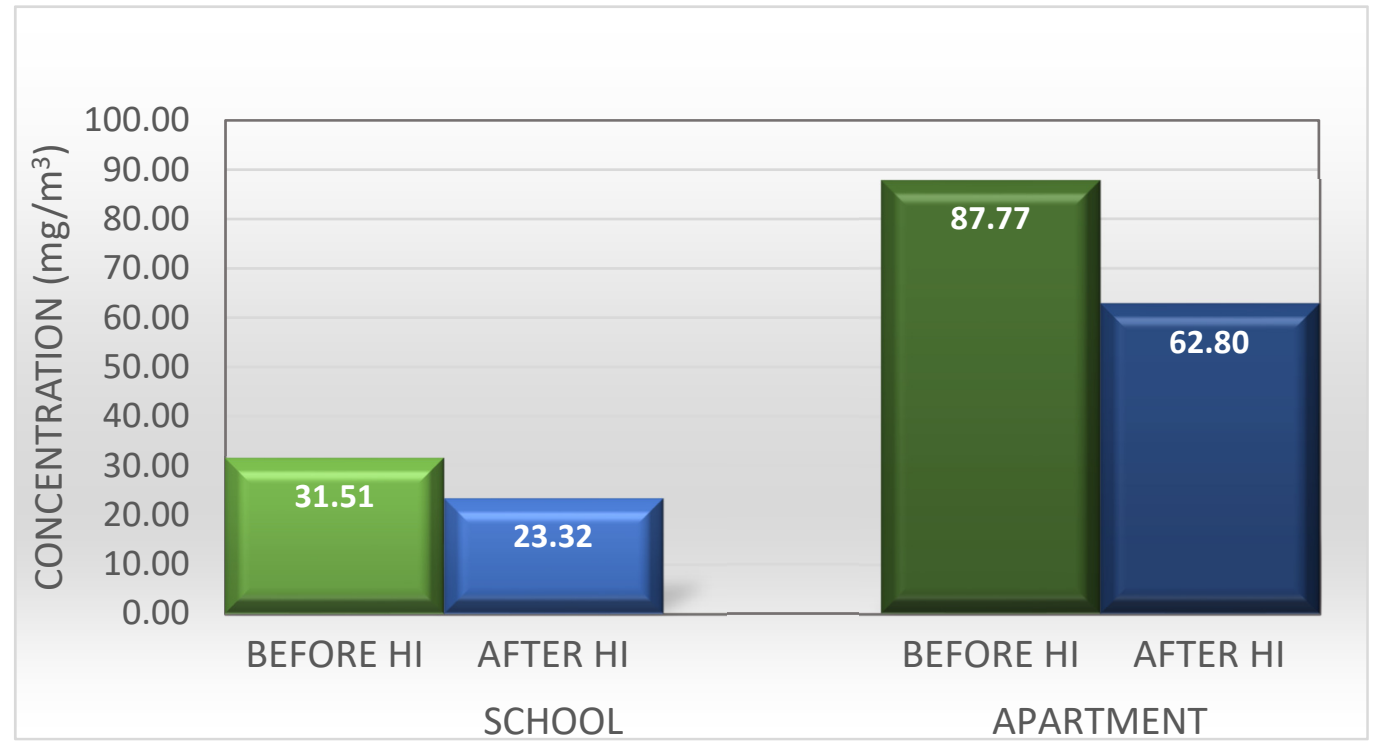

Figure 6. $\mathrm{CO}_{2}$ Concentration under calm conditions.

\subsection{Feasibility Study on Thermal Oil Boiler (B01)}

A study on the impact of two parameters-excess air percentage in air-fuel ratio and boiler load percentage- - on natural gas fuel saving percentage and annual reduction in carbon dioxide gas emissions is carried out. Both parameters are manipulated with the aim of reducing $\mathrm{CO}_{2}$ emissions.

\subsubsection{Excess Air Percentages}

Figure 7 shows the impact of different excess air percentages on natural gas fuel consumption and $\mathrm{CO}_{2}$ reduction. At a fixed excess air percentage, variations in both air and fuel flowrates have different effects on the overall fuel savings and annual reduction in carbon dioxide emissions. Therefore, two separate sets of calculations were done for each excess air percentage, i.e., the first condition limits the variation of air flowrate while the second set limits the variation of fuel flowrate.

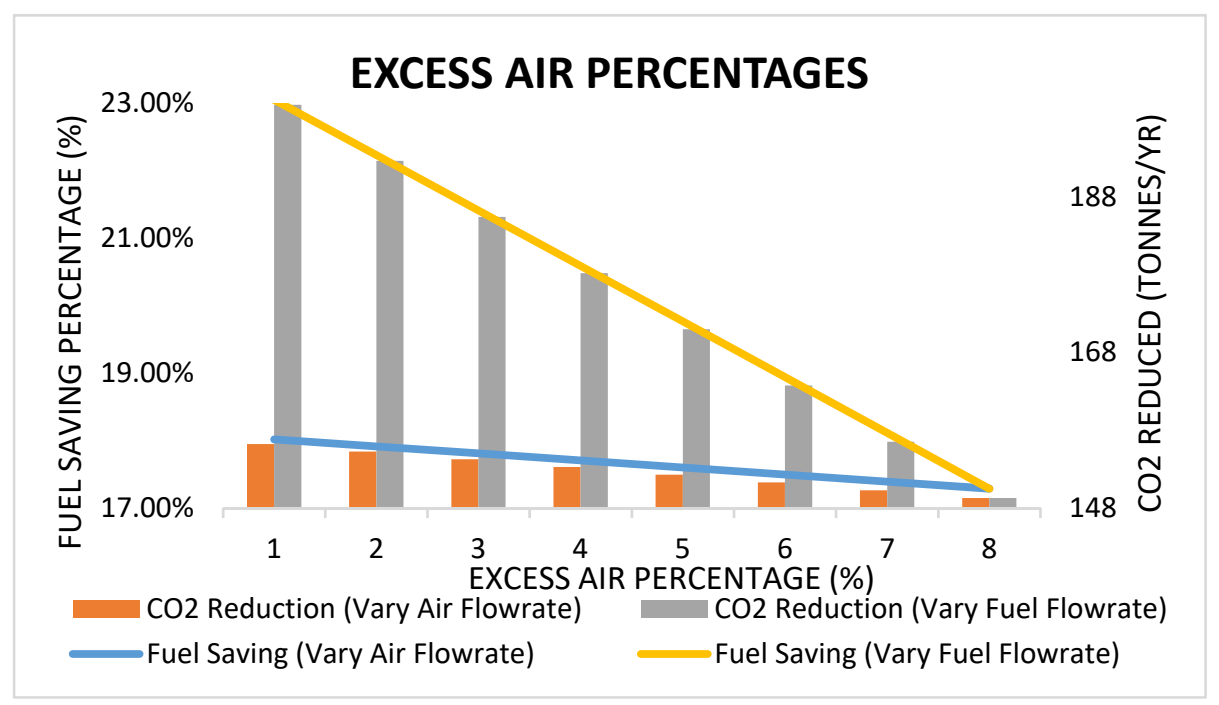

Figure 7. Fuel-Saving Percentage and CO2 Reduction under Different Excess Air Percentages.

For both sets of calculations, fuel-saving percentage is shown to be reduced with the increase in excess air percentage. This is because when the air-fuel ratio is increased, a lower temperature is achieved for the preheated stream due to the insufficient energy provided by the fuel stream. As a 
result, more fuel is consumed to provide sufficient energy to the utility stream, resulting in a decrease in the fuel-saving percentage. Under the same excess air percentage, the calculation set with a variation in fuel flowrate has a higher fuel-saving percentage than the one with fixed fuel flowrate. Fuel plays a more critical role in air-fuel ratio because the carbon atom structure within the fuel is the main source of carbon dioxide. As the excess air percentage is set from $1 \%$ to $8 \%$, correspondingly, an increase in fuel consumption is expected, leading to a decrease of carbon dioxide saving. Both lines representing fuel-saving percentages for both sets of calculations eventually meet at $8 \%$ of excess air due to the same amount of fuel and air flowrates provided to the boiler.

It is also shown in both sets of calculations that the reduction of $\mathrm{CO}_{2}$ emission decreases with the increase of excess air percentage because of the increase in fuel consumption. $\mathrm{CO}_{2}$ emission is impacted directly by the flowrate of fuel consumed due to the presence of carbon atom in the fuel. $\mathrm{CO}_{2}$ emission is inversely proportional to fuel consumption. $\mathrm{CO}_{2}$ emission will increase as more fuel is consumed. The bars show the decrease in the annual reduction of $\mathrm{CO}_{2}$ emissions for both sets of calculations, and they eventually reach the same amount of reduction in $\mathrm{CO}_{2}$ emissions at $8 \%$ of excess air.

\subsubsection{Boiler Load Percentage}

The impact on the fuel-saving ratio and reduction in $\mathrm{CO}_{2}$ emissions under different load percentages was analysed to study the feasibility of implementing the waste heat recovery system. This study is carried out by altering the load percentage of the boiler while fixing other parameters such as excess air percentage at $8 \%$, utility temperature difference at $15{ }^{\circ} \mathrm{C}$ and boiler thermal capacity at $2.5 \mathrm{MW}$. As shown in Figure 8, the variation in boiler load percentage does not impact the fuel-saving ratio. For example, a boiler with a load percentage of $50 \%$ and excess air percentages of $8 \%$ consumes 203.91 t per annum of natural gas fuel to provide thermal energy to the utility stream. With the implementation of the waste heat recovery system, the fuel consumption can be reduced by $35.25 \mathrm{t}$ per annum, which is around $17.29 \%$ of previous fuel consumption. When the load percentage of the boiler is adjusted to $80 \%$ and the excess air percentage is fixed at $8 \%$, the fuel consumption is estimated to be $326.26 \mathrm{t}$ per annum. The consumption of fuel is found to be reduced by $56.41 \mathrm{t}$ per annum, which is also $17.29 \%$ of fuel consumption. Besides this, the reduction in $\mathrm{CO}_{2}$ emissions also increases with the increase of boiler load percentage. Although the fuel-saving ratio is constant across different boiler loads, more fuel is consumed as the boiler load percentage increases and thus more fuel is saved with the implementation of the waste heat recovery system despite its constant fuel-saving ratio. This also results in increasing the amount of $\mathrm{CO}_{2}$ reduction per annum due to the increasing amount of fuel saving.

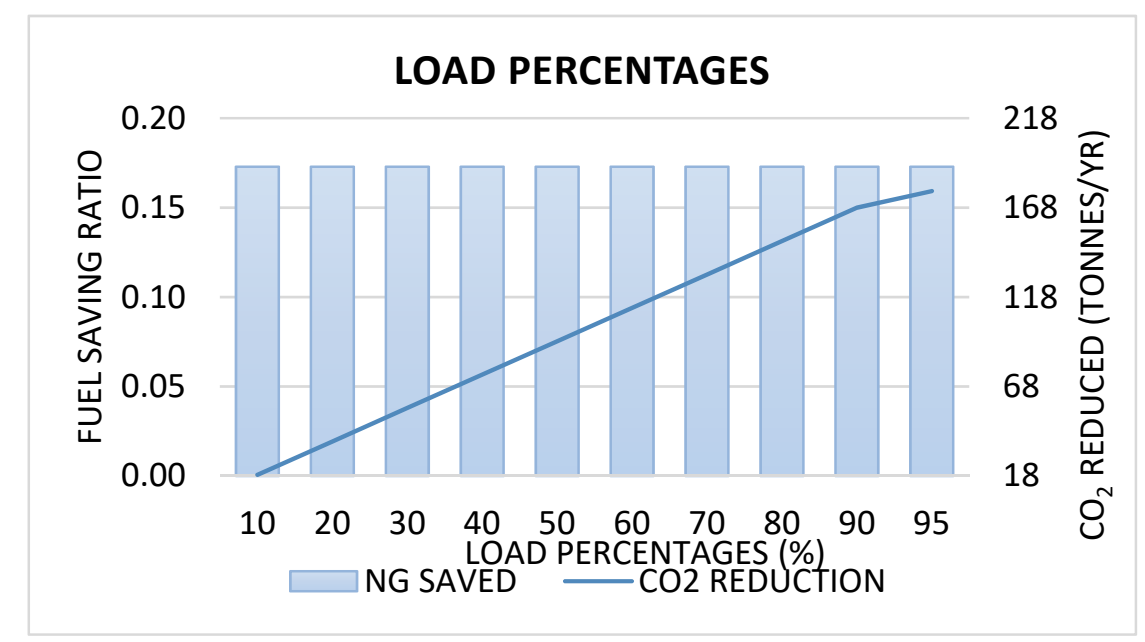

Figure 8. Fuel-Saving Ratio and $\mathrm{CO}_{2}$ Reduction under Different Load Percentages. 


\section{Conclusions}

In conclusion, the implementation of the waste heat recovery system is feasible from both economic and environmental perspectives. The implementation of the waste heat recovery system on thermal oil boiler B01 can reduce fuel consumption by $56.41 \mathrm{t}$ per annum and carbon dioxide emission by $149.29 \mathrm{t}$ per annum while the payback time of the investment is estimated to be around 85 months. A payback time of approximately 7 years makes this study feasible for a plant with a typical lifespan of 30 years. Additionally, implementing this system on B01 in year 2019 can contribute to $0.01 \%$ of the targeted reduction of $\mathrm{CO}_{2}$ emissions in the Paris Climate Agreement. Although this contribution may seem insignificant, it should be noted that this is the contribution from a boiler with an exact thermal capacity of $2.5 \mathrm{MW}$. It is also shown in the case study that the concentration levels of $\mathrm{CO}_{2}$ emitted to nearby communities with high population density are well below the $\mathrm{CO}_{2}$ exposure limit set by Wisconsin Department of Health and Services. With the implementation of the waste heat recovery system, the $\mathrm{CO}_{2}$ concentration levels at both the residential apartment and school area are further reduced, thus improving the air quality.

While this manuscript describes a conceptual study, proper physical setup as well as monitoring are needed in order to realise the physical reduction of $\mathrm{CO}_{2}$ as well as energy conservation. In order to further reduce the energy consumption and environmental impact of the plant, it is recommended that the plant invests in a combined heat power system to harvest waste heat for power production. Additionally, since the current postulation focuses only on the utility site, a suggestion is also made to implement total site heat integration to further reduce the energy consumption of the plant.

Author Contributions: K.S.K. and V.S.C. proposed the main idea. S.J.C. performed the calculation as well as generated the excel generator and respective results. C.M.C. and V.S.C. supervised the project and provided useful discussion along the project. K.S.K. and S.J.C. validated the final result and wrote the manuscript.

Funding: This research received no external funding.

Acknowledgments: The authors acknowledge the contribution from KL-Kepong Oleomas Sdn. Bhd for the data input and continuous support throughout the project.

Conflicts of Interest: The authors declare no conflict of interest.

\section{Abbreviations}

$\begin{array}{ll}A P H & \text { Air Preheater } \\ \mathrm{CO}_{2} & \text { Carbon Dioxide Gas } \\ \text { CTST } & \text { Conventional Total Site Targeting } \\ D O E & \text { Department of Environment Malaysia } \\ D P & \text { Dew Point } \\ E P A & \text { United States Environmental Protection Agency } \\ H I & \text { Heat Integration } \\ L N G & \text { Liquefied Natural Gas } \\ N G & \text { Natural Gas Fuel } \\ P & \text { Pressure } \\ P * & \text { Newly Conditioned Flue Gas Pressure } \\ P B T & \text { Payback Period } \\ R O R & \text { Rate of Return } \\ T & \text { Temperature } \\ T * & \text { Newly Conditioned Flue Gas Temperature } \\ T_{\text {premix }} & \text { Premix Temperature } \\ T S H I & \text { Total Site Heat Integration } \\ \text { UTST } & \text { Unified Total Site Targeting }\end{array}$




\section{Appendix A}

Table A1. Limit values and technical standards for boiler [34].

\begin{tabular}{|c|c|c|c|c|}
\hline FUEL TYPE & POLLUTANT & CAPACITY & LIMIT VALUE & MONITORING \\
\hline \multirow{10}{*}{ Solid and Liquid Fuels } & $\begin{array}{l}\text { Sum of } \mathrm{SO}_{2} \text { and } \mathrm{SO}_{3} \\
\text { expressed of } \mathrm{SO}_{2}\end{array}$ & $>10 \mathrm{MW}_{\mathrm{e}}$ & $500 \mathrm{mg} / \mathrm{m}^{3}$ & Continuous * \\
\hline & $\begin{array}{l}\text { Sum of } \mathrm{NO}_{2} \text { and } \mathrm{NO}_{3} \\
\text { expressed of } \mathrm{NO}_{2}\end{array}$ & $>10 \mathrm{MW}_{\mathrm{e}}$ & $500 \mathrm{mg} / \mathrm{m}^{3}$ & Continuous * \\
\hline & Hydrogen Chloride $(\mathrm{HCl})$ & $10<\mathrm{C}<100 \mathrm{MW}_{\mathrm{e}}$ & $200 \mathrm{mg} / \mathrm{m}^{3}$ & Periodic \\
\hline & Hydrogen Chloride $(\mathrm{HCl})$ & $\geq 100 \mathrm{MW}_{\mathrm{e}}$ & $100 \mathrm{mg} / \mathrm{m}^{3}$ & Periodic \\
\hline & Hydrogen Fluoride (HF) & $10<\mathrm{C}<100 \mathrm{MW}_{\mathrm{e}}$ & $30 \mathrm{mg} / \mathrm{m}^{3}$ & Periodic \\
\hline & Hydrogen Fluoride (HF) & $\geq 100 \mathrm{MW}_{\mathrm{e}}$ & $15 \mathrm{mg} / \mathrm{m}^{3}$ & Periodic \\
\hline & Carbon Monoxide (CO) & $>10 \mathrm{MW}_{\mathrm{e}}$ & $200 \mathrm{mg} / \mathrm{m}^{3}$ & Continuous * \\
\hline & Total PM & $>10 \mathrm{MW}_{\mathrm{e}}$ & $50 \mathrm{mg} / \mathrm{m}^{3}$ & Continuous* \\
\hline & Mercury (Hg) & $>10 \mathrm{MW}_{\mathrm{e}}$ & $0.03 \mathrm{mg} / \mathrm{m}^{3}$ & Periodic \\
\hline & PCDD/PCDF & $>10 \mathrm{MW}_{\mathrm{e}}$ & $0.1 \mathrm{ng} \mathrm{TEQ} / \mathrm{m}^{3}$ & Periodic \\
\hline \multirow{3}{*}{ Gaseous Fuels } & $\begin{array}{l}\text { Sum of } \mathrm{NO}_{2} \text { and } \mathrm{NO}_{3} \\
\text { expressed of } \mathrm{NO}_{2}\end{array}$ & $>10 \mathrm{MW}_{\mathrm{e}}$ & $350 \mathrm{mg} / \mathrm{m}^{3}$ & Continuous* \\
\hline & Carbon Monoxide (CO) & $>10 \mathrm{MW}_{\mathrm{e}}$ & $50 \mathrm{mg} / \mathrm{m}^{3}$ & Continuous * \\
\hline & Total PM & $>10 \mathrm{MW}_{\mathrm{e}}$ & $5 \mathrm{mg} / \mathrm{m}^{3}$ & Periodic \\
\hline
\end{tabular}

* Averaging time for continuous monitoring is $30 \mathrm{~min}$.

Table A2. Stack gas emission standards [35].

\begin{tabular}{|c|c|c|}
\hline POLLUTION & EMISSION SOURCES & STANDARDS \\
\hline \multirow{6}{*}{ 1. Dark Smoke } & 1.1. Solid Fuel Equipment to Facilities & Ringlemann Chart No.2 \\
\hline & 1.2. Equipment Using Other Types of Fuel & Ringlemann Chart No.1 \\
\hline & 2.1. Facilities Used for the Heating of Metal & $0.2 \mathrm{gm} / \mathrm{Nm}^{3}$ \\
\hline & Other Thank Cold Blast Foundry Cupola & \\
\hline & $\begin{array}{l}\text { 2.2. Facilities Discharging Dust Containing } \\
\text { Asbestos and Free Silica }\end{array}$ & $0.12 \mathrm{gm} / \mathrm{Nm}^{3}$ \\
\hline & 2.3. Portland Cement Manufacturing: & \\
\hline \multirow{6}{*}{ 2. Dust } & 2.3.1. Kiln & $0.2 \mathrm{gm} / \mathrm{Nm}^{3}$ \\
\hline & 2.3.2. Clinker, Cooler, Grinder, Others & $0.1 \mathrm{gm} / \mathrm{Nm}^{3}$ \\
\hline & 2.4. Asphalt Concrete/Bituminous Mixing Plant: & \\
\hline & 2.4.1. Stationary Plant & $0.3 \mathrm{gm} / \mathrm{Nm}^{3}$ \\
\hline & 2.4.2. Mobile Plant & $0.4 \mathrm{gm} / \mathrm{Nm}^{3}$ \\
\hline & 2.5. Other Sources & $0.4 \mathrm{gm} / \mathrm{Nm}^{3}$ \\
\hline \multicolumn{3}{|l|}{ 3. Metal and Metallic Compound } \\
\hline 3.1. Mercury & Industry & $0.01 \mathrm{gm} / \mathrm{Nm}^{3}$ \\
\hline 3.2. Cadmium & Industry & $0.015 \mathrm{gm} / \mathrm{Nm}^{3}$ \\
\hline 3.3. Lead & Industry & $0.025 \mathrm{gm} / \mathrm{Nm}^{3}$ \\
\hline 3.4. Antimony & Industry & $0.025 \mathrm{gm} / \mathrm{Nm}^{3}$ \\
\hline 3.5. Arsenic & Industry & $0.025 \mathrm{gm} / \mathrm{Nm}^{3}$ \\
\hline 3.6. Zinc & Industry & $0.1 \mathrm{gm} / \mathrm{Nm}^{3}$ \\
\hline 3.7. Copper & Industry & $0.1 \mathrm{gm} / \mathrm{Nm}^{3}$ \\
\hline \multicolumn{3}{|l|}{ 4. Gases } \\
\hline 4.1. Acid Gases & Sulphuric Acid Manufacturing & $3.5 \mathrm{gm}$ of $\mathrm{SO}_{3} / \mathrm{Nm}^{3}$ and No Persistent Mist \\
\hline 4.2. Sulphuric Acid Mist or $\mathrm{SO}_{3}$ & Any Sources Other Than 4.1. & $0.2 \mathrm{gm}$ of $\mathrm{SO}_{3} / \mathrm{Nm}^{3}$ and No Persistent Mist \\
\hline 4.3. Chlorine Gas & Any Source & $0.2 \mathrm{gm}$ of $\mathrm{HCl} / \mathrm{Nm}^{3}$ \\
\hline 4.4. $\mathrm{HCl}$ & Any Source & $0.2 \mathrm{gm}$ of $\mathrm{HCl} / \mathrm{Nm}^{3}$ \\
\hline \multicolumn{3}{|l|}{$\begin{array}{l}\text { 4.5. Fluorine, Hydrofluoric } \\
\text { Acid, Inorganic Compound }\end{array}$} \\
\hline 4.6. - do - & Any Sources Other Than 4.5 . & $0.1 \mathrm{gm}$ of Hydrofluoric $\mathrm{Acid} / \mathrm{Nm}^{3}$ \\
\hline 4.7. Hydrogen Sulphide & Any Source & $5 \mathrm{ppm}(\mathrm{Vol} \%)$ \\
\hline 4.8. $\mathrm{NO}_{\mathrm{X}}$ & Acid Nitric Manufacturing & $\begin{array}{l}1.7 \mathrm{gm} \text { of } \mathrm{SO}_{3} / \mathrm{Nm}^{3} \text { and Substantially } \\
\text { Colourless }\end{array}$ \\
\hline 4.9. $\mathrm{SO}_{\mathrm{X}}$ & Any Sources Other Than 4.8 . & $2.0 \mathrm{gm} \mathrm{SO}_{3} / \mathrm{Nm}^{3}$ \\
\hline
\end{tabular}




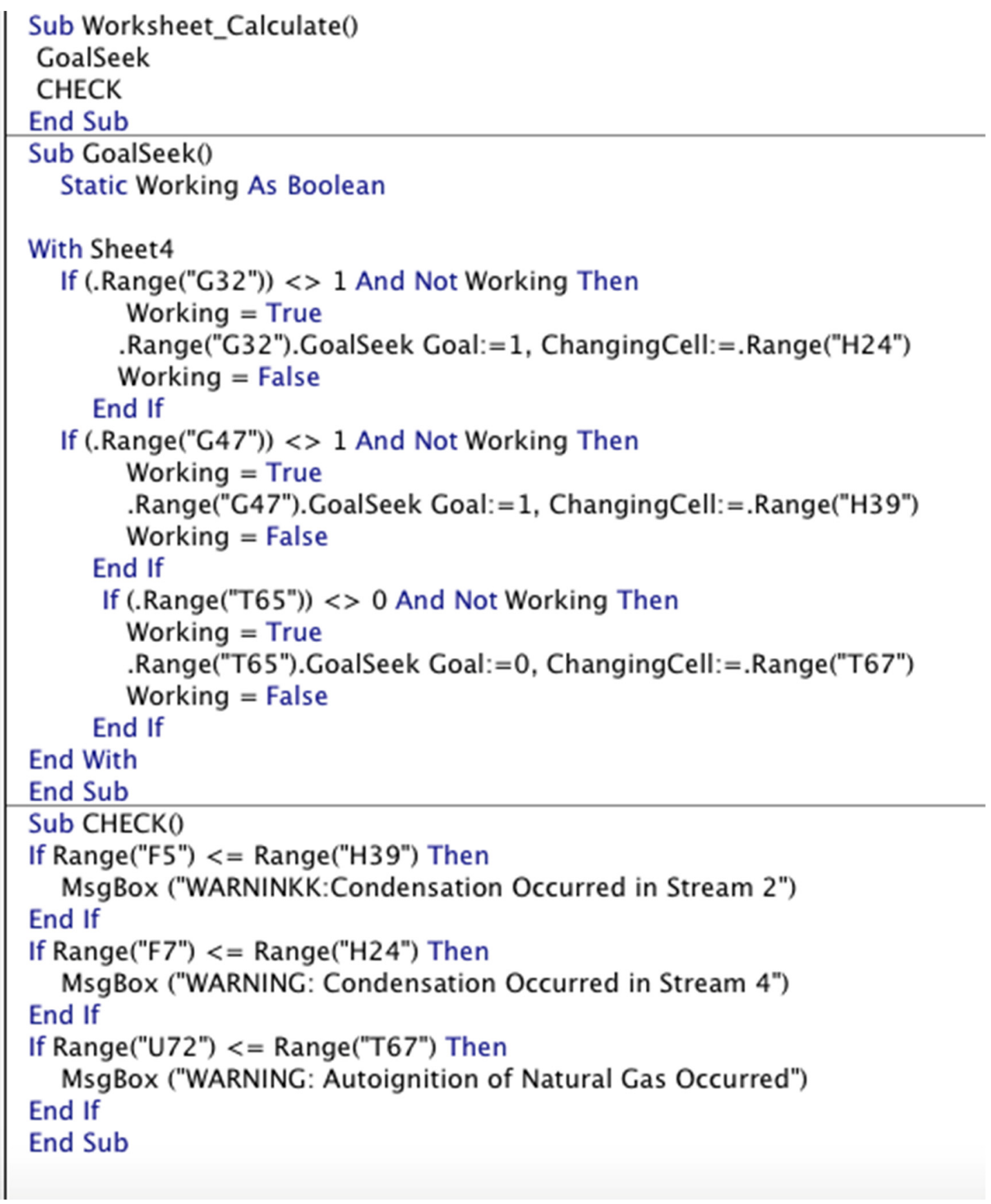

Figure A1. Auto goal-seek function in Visual Basic.

The auto goal-seek function that is set here is meant to read the data range given by insertion of temperature input. It will then perform a proper calculation to define the work phase of the temperature output from the flue gas after economizer. If there is potential condensation, a warning sign will pop up to warn the user. 


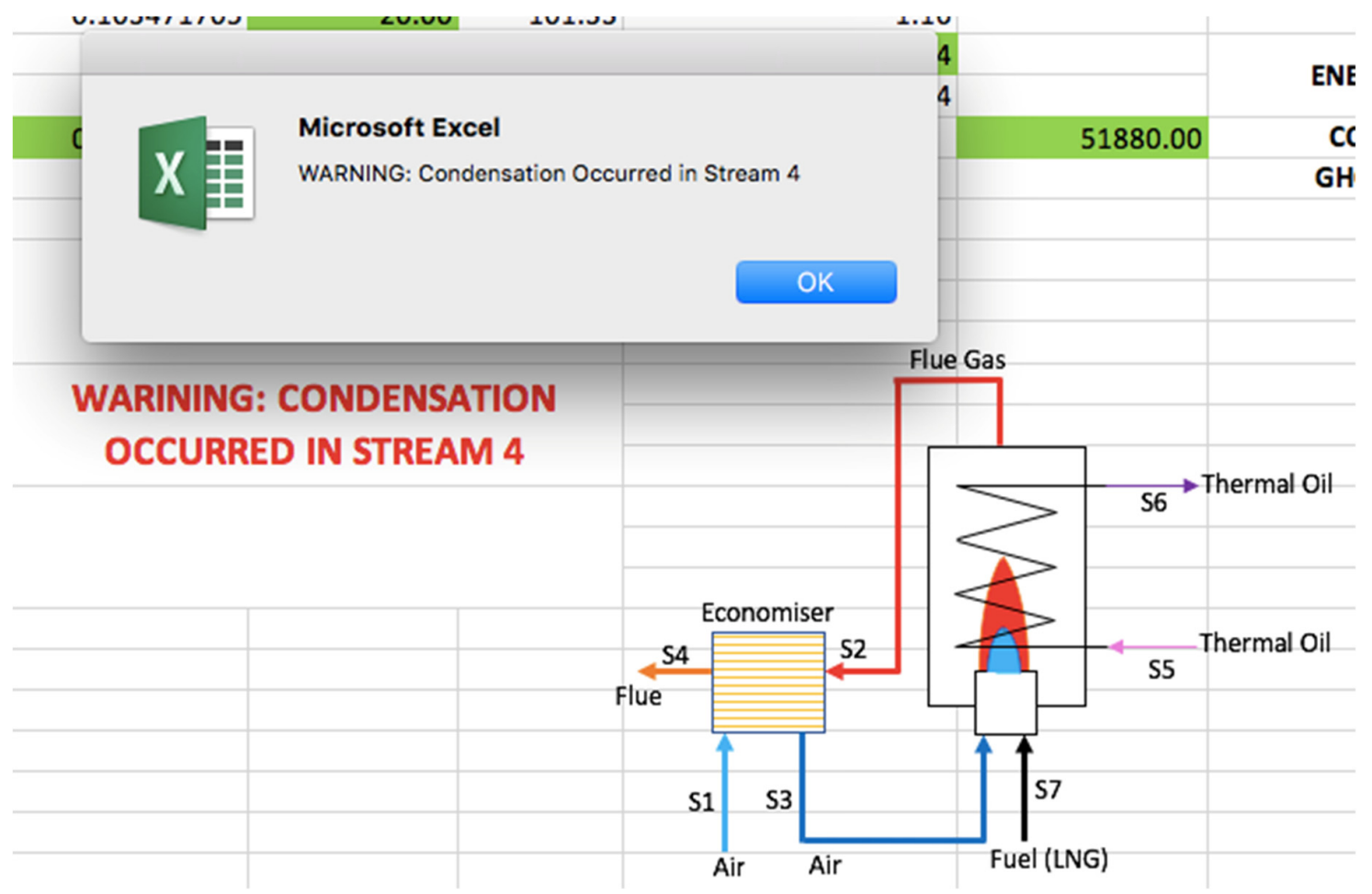

Figure A2. Warning when condensation of Flue Gas occurred. 


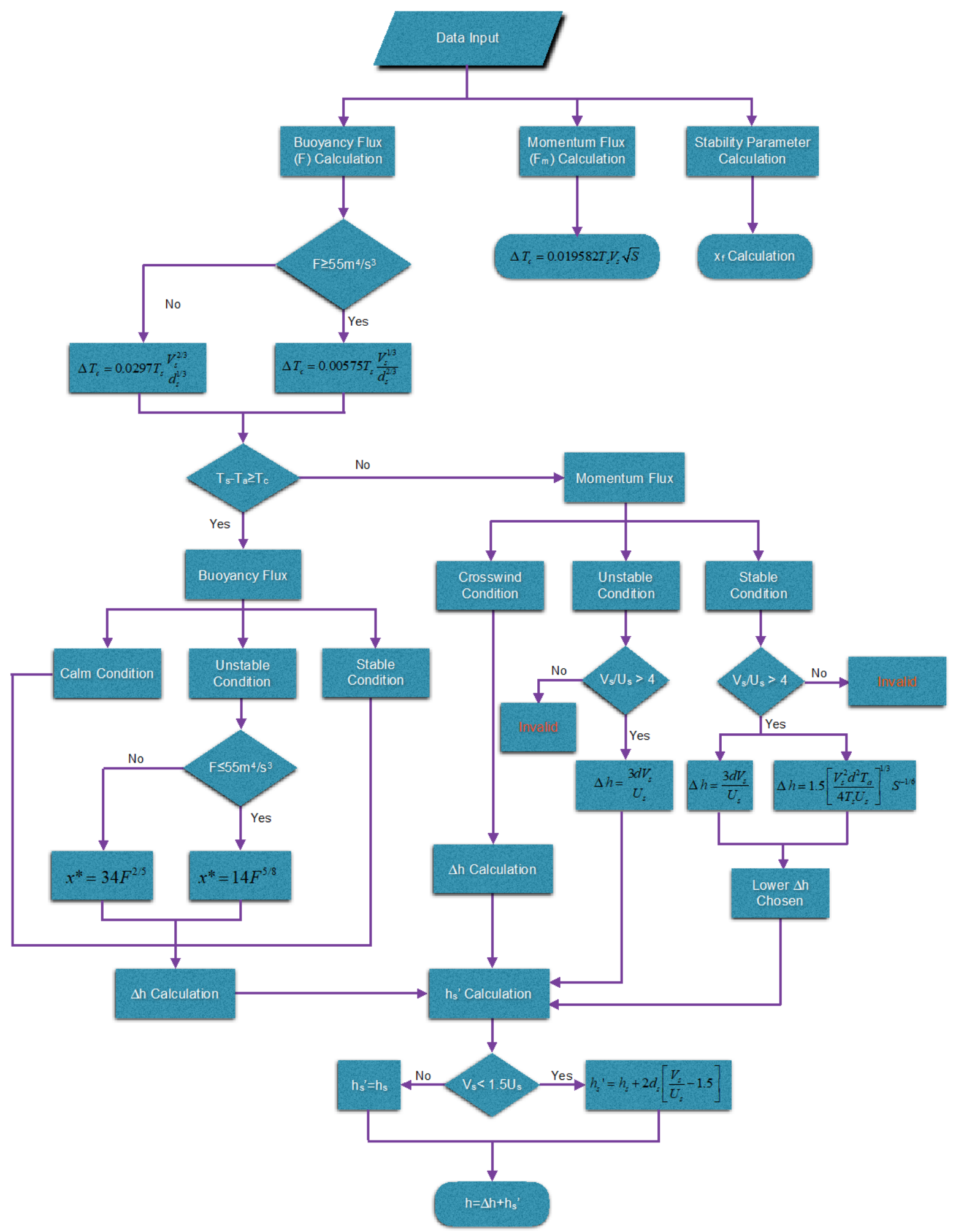

Figure A3. Flow Chart for Detailed Algorithm used in Calculation of Plume Rise Calculation.

\section{References}

1. Yang, S.T. Bioprocessing-From Biotechnology to Biorefinery. In New Technologies and Applications; Elsevier: Dublin, OH, USA, 2007; pp. 1-24. 
2. European Oleochemcials \& Allied Products Group, Challenges and Potential of Biomass \& Biofuels for the European Oleochemical Industry. 1 June 2006. Available online: http://www.europarl.europa.eu/hearings/ 20060601/itre/decooman_en.pdf (accessed on 22 September 2018).

3. Malaysia Palm Oil Council (MPOC). "Palm Oil". 2006. Available online: http://www.mpoc.org.my/Palm_Oil. aspx (accessed on 22 September 2018).

4. Malaysia Palm Oil Council (MPOC). Malaysian Palm Oil Industry. 7 April 2014. Available online: http://www.mpoc.org.my/Malaysian_Palm_Oil_Industry.aspx (accessed on 22 September 2018).

5. Hazimah, A.H. Palm Oil: Going Beyong Basic Oleochemicals. 12 April 2012. Available online: http: //www.mpoc.org.my/upload/DrHazimah_POTS_PHP.pdf (accessed on 22 September 2018).

6. Research, G.V. Oleochemicals Market Analysis and Segment Forecasts to 2020; Grand View Research: San Francisco, CA, USA, 2019.

7. Tenaga, S. National Energy Balance 2016; Suruhanjaya Tenaga: Putrajaya, Malaysia, 2018.

8. Tenaga, S. Final Energy Demand; Malaysia Energy Information Hub: Putrajaya, Malaysia, 2019.

9. Info, W.D. Energy Consumption in Malaysia, World Data Info. Available online: https://www.worlddata. info/asia/malaysia/energy-consumption.php (accessed on 22 September 2018).

10. Linnhoff, B.; Flower, J.R. Synthesis of heat exchanger networks: I. Systematic generation of energy optimal networks. AiChe J. 1978, 24, 633-642. [CrossRef]

11. Klemeš, J.J.; Kravanja, Z. Forty years of Heat Integration: Pinch Analysis (PA) and Mathematical Programming (MP). Curr. Opin. Chem. Eng. 2013, 2, 461-474. [CrossRef]

12. Klemeš, J.; Friedler, F.; Bulatov, I.; Varbanov, P. Sustainability in the Process Industry -Integration and Optimization; McGraw-Hill: New York, NY, USA, 2010.

13. Dhole, V.R.; Linnhoff, B. Total site targets for fuel, co-generation, emissions, and cooling Author links open overlay panel. Comput. Chem. Eng. 1993, 17, 101-109. [CrossRef]

14. Tarighaleslami, A.H.; Walmsley, T.G.; Atkins, M.J.; Walmsley, M.R.; Neale, J.R. A Comparison of Utility Heat Exchanger Network Synthesis for Total Site Heat Integration Methods. Chem. Eng. Trans. 2017, 61, 775-780.

15. Marto, S.; Svensson, E.; Harvey, S. Investigating Operability Issues of Heat Integration for Implementation in the Oil re Ning Industry; ECEEE Industry Proceedings: Stockholm, Sweden, 2016.

16. Liew, P.Y.; Theo, W.L.; Alwi, S.R.W.; Lim, J.S.; Manan, Z.A.; Klemeš, J.J.; Varbanov, P.S. Total Site Heat Integration planning and design for industrial, urban and renewable systems. Renew. Sustain. Energy Rev. 2017, 68, 964-985. [CrossRef]

17. Sang, L.K.; Kee, C.K. Air Quality Impact Analysis; Malaysia Meteorological Service \& University of Malaya: Kuala Lumpur, Malaya, 1985.

18. Indra, E.; Sinha, N.; Ghose, M.K.; Singh, G.; Srivastava, S.; Sinha, I. Classification of air pollution dispersion MODELS: A critical review. In Proceedings of the National Seminar on Environmental Engineering with Special Emphasis on Mining Environment, Shibpur, India, 19-20 March 2004; pp. 19-20.

19. Lutman, E.R.; Jones, S.R.; Hill, R.A.; McDonald, P.; Lambers, B. Comparison between the predictions of a Gaussian plume model and a Lagrangian particle dispersion model for annual average calculations of long-range dispersion of radionuclides. J. Environ. Radioact. 2004, 75, 339-355. [CrossRef]

20. Abdel-rahman, A.A. On the atmospheric dispersion and gaussian plume model. In Proceedings of the 2nd International Conference on Waste Management, Water Pollution, Air Pollution, Indoor Climate, Corfu, Greece, 26 October 2008.

21. Taylor, G. Diffusion by Continuous Movements. Proc. Lond. Math. Soc. 1922, 2, 196-212. [CrossRef]

22. Lents, J.; Walsh, M.; He, K.; Davis, N.; Osses, M.; Tolvett, S.; Liu, H. Air Quality Modelling. Available online: http://www.aqbook.org/read/?page=254 (accessed on 8 November 2018).

23. Sutton, O.G. The problem of diffusion in the lower atmosphere. Q. J. R. Meteorol. Soc. 1947, 73, $257-281$. [CrossRef]

24. Sutton, O.G. The Theoretical Distribution of Airborne Pollution from Factory Chimneys. Q. J. R. Meteorol. Soc. 1947, 73, 426-436. [CrossRef]

25. Lagzi, I.; Mészáros, R.; Gelybó, G.; Leelőssy, Á. Gaussian Dispersion Models; Eötvös Loránd University, Consortium: Budapest, Hungary, 2013.

26. Brusca, S.; Farnoso, F.; Lanzafame, R.; Mauro, S.; Farrano, A.M.C.; Monforte, P. Theoretical and experimental study of Gaussian Plume model in small scale system. In Proceedings of the 71st Conference of the Italian Thermal Machines Engineering Association, ATI2016, Turin, Italy, 14-16 September 2016. 
27. Khaniabadi, Y.O.; Sicard, P.; Taiwo, A.M.; Marco, A.D.; Esmaeili, S.; Rashidi, R. Modeling of particulate matter dispersion from a cement plant: Upwind- downwind case study. J. Environ. Chem. Eng. 2018, 6, 3104-3110. [CrossRef]

28. DoItYourself, 5 Common Chimney Flue Problems to Avoid, DoItYourself. Available online: https://www. doityourself.com/stry/5-common-chimney-flue-problems-to-avoid (accessed on 12 December 2018).

29. Earth System Research Laboratory. Trends in Atmospheric Carbon Dioxide, National Oceanic and Atmospheric Administration. 2019. Available online: https://www.esrl.noaa.gov/gmd/ccgg/trends/global. html (accessed on 10 March 2019).

30. NGIFSS. (GISS). Global Temperature. NASA, 6 March 2019. Available online: https://climate.nasa.gov/vitalsigns/global-temperature/ (accessed on 10 March 2019).

31. Ministry of Internationa Trade and Industry (MITI). Malaysia and the United Nations Framework Convention on Climate Change (UNFCCC)-The Paris Agreement. 11 December 2017. Available online: https://www. miti.gov.my/miti/resources/Article_on_Malaysia_UNFCCC-_Paris_Agreement.pdf?mid=572 (accessed on 10 March 2019).

32. Lindsey, R. Climate Change: Atmospheric Carbon Dioxide," Climate.Gov. 1 August 2018. Available online: https://www.climate.gov/news-features/understanding-climate/climate-change-atmospheric-carbondioxide (accessed on 12 March 2019).

33. Wisconsin Department of Health Services, Carbon Dioxide, Wisconsin Department of Health Services. 20 November 2018. Available online: https://www.dhs.wisconsin.gov/chemical/carbondioxide.htm (accessed on 10 March 2019).

34. Gazette, F.G. Environmental Quality (Clean Air) Regulations 2014. 4 June 2014. Available online: http://www.federalgazette.agc.gov.my/outputp/pua_20140604_P.U.\%20\%28A\%29\%20151-peraturanperaturan \%20kualiti\%20alam\%20sekeliling\%20\%28udara\%20bersih\%29\%202014.pdf (accessed on 8 November 2018).

35. Department of Environment Malaysia, Environmental Requirements: A Guide for Investors. October 2010. Available online: http://www.doe.gov.my/eia/wp-content/uploads/2012/03/A-Guide-For-Investors1.pdf (accessed on 8 November 2018). 